\title{
A Story of Mother's Struggle in the Rural: The Narratives of Children Learning Mentoring during the Covid-19 Outbreak
}

\author{
Suhirman ${ }^{1}$, Kasman $^{2}$, Rohman $^{3}$, Emzinetri $^{4}$, Ihsan Rahmat ${ }^{5}$ \\ \{suhirmn@gmail.com¹,kasman@stain-madina.ac.id², rohman@stain-madina.ac.id², \\ emzinetriaff@gmail.com ${ }^{4}$,ihsanrahmat@iainbengkulu.ac.id $\left.{ }^{5}\right\}$ \\ Institut Agama Islam Negeri Bengkulu, Indonesia ${ }^{1}$, Sekolah Tinggi Agama Islam Negeri Mandailing \\ Natal, Indonesia ${ }^{2}$, Sekolah Tinggi Agama Islam Negeri Mandailing Natal, Indonesia ${ }^{3}$, Institut Agama \\ Islam Negeri Bengkulu, Indonesia ${ }^{4}$, Institut Agama Islam Negeri Bengkulu, Indonesia ${ }^{5}$
}

\begin{abstract}
This paper discusses the mother's struggle for children learning mentoring during the Covid-19 Outbreak in the Rural. We argue the unpreparedness of the education system in dealing with crises puts mothers in unpredictable and submissive situations. Interesting research because earlier studies have not been able to properly reveal their role. The narrative approach is used to access heroic stories, sacrifices, and full of meaning. We collected 47 informant data, but only 16 women were willing to be interviewed in-depth using six open-ended questions. We find five key narratives of mothers' experiences: the knowledge struggle, the technology struggle, the economic struggle, the emotional struggle, and the physical struggle. Unexpectedly before, mothers also suffer fatigue and pain for physical struggle. Gender stereotypes and social norms as village women are discussed. This research emphasizes the importance of education policy intervention in times of crisis, especially in the areas of human resources, economy, and access to information.
\end{abstract}

Keywords: Risk online education; Parent-child monitoring; E-Learning impact; the Covid-19 outbreak.

\section{Introduction}

Since the circular letter issued by the Minister of Education and Culture No. 4 of 2020 with reference to the Implementation of Education amid the Coronavirus Disease (Covid-19) Emergency, the face of education in Indonesia has experienced drastic changes. They are seen in the six rules, one of which is the policy implementation of learning from home through the distance system (online), which is an unprecedented condition in the history of national education. This situation is a direct impact of the closure of most public facilities and educational services at all levels. Social restrictions are initiated for all citizens, including students who are strictly prohibited from leaving home except for the limited purposes permitted by the Orders. Glover et al. [1], Yousefpour et al. [2] and Nicola et al. [3] review each of the policies taken aiming to put a halt to Covid-19, despite the fact that Viner et al. [4] found the closure of school services had no major impact, only preventing $2-4 \%$ of the total of deaths, far less than other social distance interventions.

The patterns of mothers and children's daily life activities at home changes drastically. 
Social distancing policies implemented outside cause confinement of family members. On the one hand, the interaction intensity between family members is increasing, which potentially trigger mental health problems [5],[6],[7],[8]. Most parents do not commute to work anymore as they have to accomplish all the office jobs at their dwelling house because of the Work From Home policy, this becomes more difficult. They must manage family life, office work, and their children's needs for learning on daily bases. Some of them have to do smart work, and handle the time and space to work with children around may be very problematic. On the other hand, parents have more expanded opportunities to educate their children than they have had before. Children are highly dependent on the ability of parents to promote positive development and new learning experiences [9],[10]. For example, Amlen [11] suggests that during the quarantine, parents ask their children to play guessing games or what Osmanski [12] advices games such as arranging treasure hunts, training dogs, and playing word guessing.

Earlier studies during the Covid-19 outbreak regarding the role of parents in assisting children's learning at home has been conducted. However, that cannot be said to have covered the void of educational literature in this time of crisis. Past studies seem to superficially only explain the role of parents in general and use diverse respondents. Dewi [13] and Cahyati \& Kusumah [14] offered questions that had been prepared, then described the results of the respondents' answers. Hikam [15], Lutfi \& Ahsani [16], and Wardhani \& Krisnani [17] generally explained their findings that there was mentoring, understanding of learning styles, providing information, and providing facilities. As far as we are searching, there is no research that focuses on narrating the struggle of mothers in meeting the demands of children's education during the Covid-19 period. The use of narratives is believed to be able to reach data that is not conveyed by other approaches.

In our focus we will narrate the struggle of mothers in their efforts to assist children's learning in the time of the Covid-19 pandemic in the context of remote villages. Then, the challenges they might faces in the future will also be revealed. While policies tend to equalize the parents' environments and conditions, we argue that in the context of regionalism, the unpreparedness of the education system in dealing with crises has caused mothers to struggle with unpredictable situations and surrender. Jægera \& Blaabæk's found that Covid-19 actually increases inequality in learning opportunities including access to reading material [18]. Students from remote areas became marginalized during this pandemic [19]. This study is important and relevant to provide input for educational intervention programs in times of crisis.

\section{Method}

\subsection{Research Design}

We used a narrative approach to obtain and analyze the experience of the struggling mothers in assisting children's learning in the difficult times of the Covid-19 pandemic in remote villages. Riessman suggests a narrative approach has a pattern similar to storytelling in order to gain insight into some aspects of a person's life that cannot be reached by other qualitative approaches [20]. We assess by paying a full attention to the stories of mothers to make interpretation or find relationship among online system education in difficult times, limited resources and the stories they had from their encounters of the situation. We realize that that this approachdid not a hundred percent represent the whole struggle of mothers in 
remote areas. However, we put our focus on the constructions and interpretations of women who had very limited resources, but were forced to survive in hard times which they shared through storytelling [21],[22].

\subsection{Samples and Settings}

Our team's first initial step was to contact several students at unversities to gain information about prospective respondents' from remote areas in the districts of North Bengkulu, Central Bengkulu, and South Bengkulu within the scope of Province Bengkulu, Indonesia. We colected 47 names of potential participants, along with their cellphone numbers and locations. Through consideration of sample criteria, access to locations, and communication networks, only 24 people were qualified. We interviewed the participants using mobile phones and videocall from Whatsapp. For the final data, there were only 16 of them giving their consent to take part in the full interview (see: Table 1). The mothers were considered to have eligible participant criteria if they had the following situations: (1) Having children attending elementary school or junior high school with active student status; 2) living in a remote village at least $30 \mathrm{~km}$ away from the city center/district, (2) having assisted children in the learning process at least for the last one month, (4) giving their written consent prior to participating.

\subsection{Data Collection}

Each of the participants was interviewed 2-3 times with an average duration of about 46.3 minutes for one interview, depending on the need to the data. Every word from the interview was recorded, transcribed and reviewed. The participants were asked for another interview when needed. Primary data collection took two months (May - June 2020). The constraints in data collection were generally technical problems, such as bad signals, less supportive participant mobile devices, crying children around them, and inaccurate participant's responses. The adjustment of the interview schedule of some paticipants was also challenging because they had personal duties and work schedules on their sides.

Each interview was launched by offering simple questions such as personal data, children's data, and description of pariticpants' living places. The use of humor in the interview was emphasized to make the participants relaxed, comfortable, and undisturbed by time. Six items of open-ended questions were prepared, which started with a question 'Can you tell us how your family is now?' (see: Table 2). This refers to Webster \& Mertova's guide that structuring interview questions for a narrative approach would encourage reflection and sharing longer sections [23].

\begin{tabular}{|c|c|c|c|c|c|c|c|c|}
\hline \multirow[b]{2}{*}{ No } & \multicolumn{4}{|c|}{ Data of Mother } & \multicolumn{2}{|c|}{$\begin{array}{c}\text { Data of } \\
\text { Children }\end{array}$} & \multicolumn{2}{|c|}{ Location } \\
\hline & $\begin{array}{l}\text { Particip } \\
\text { ant code }\end{array}$ & Age & $\begin{array}{l}\text { Educati } \\
\text { on Level }\end{array}$ & $\begin{array}{l}\text { Occupati } \\
\text { on }\end{array}$ & $\begin{array}{l}\text { Particip } \\
\text { ant code }\end{array}$ & $\begin{array}{c}\text { Educati } \\
\text { on } \\
\text { Level }\end{array}$ & Vilage & $\begin{array}{c}\text { Distance to } \\
\text { nearest } \\
\text { city/district }\end{array}$ \\
\hline 1 & A3-Rya & $35 \mathrm{yrs}$ & DIII & Midwife & Rya-A3 & SD & Padang Siring & $73 \mathrm{KM}$ \\
\hline 2 & A2-Hna & $32 \mathrm{yrs}$ & SMA & Non-Job & Hna-A2 & SD & Dusun Baru II & $88 \mathrm{KM}$ \\
\hline 3 & $\mathrm{~A} 2-\mathrm{Nta}$ & $43 \mathrm{yrs}$ & SMA & Fisherman & Nta-A2 & SD & Kahyapu & $200 \mathrm{KM}$ \\
\hline
\end{tabular}




\begin{tabular}{|c|c|c|c|c|c|c|c|c|}
\hline 4 & A2-Arm & $40 \mathrm{yrs}$ & SMK & Farmer & $\begin{array}{c}\text { Arm-A2 } \\
\text { Arm-A21 }\end{array}$ & $\begin{array}{l}\text { SD } \\
\text { SD }\end{array}$ & Gedung Sako & $181 \mathrm{KM}$ \\
\hline 5 & A1-Uta & $36 \mathrm{yrs}$ & SMP & Farmer & Uta-A1 & SDIT & Sebayur Jaya & $32 \mathrm{KM}$ \\
\hline 6 & A4-Wda & 34 yrs & Strata 1 & ES Teacher & $\begin{array}{c}\text { Wda-A4 } \\
\text { Wda-A41 }\end{array}$ & $\begin{array}{l}\text { SD } \\
\text { SD }\end{array}$ & Lubuk Mindai & $26 \mathrm{KM}$ \\
\hline 7 & A2-Smi & $35 \mathrm{yrs}$ & SMK & Farmer & $\begin{array}{c}\text { Smi-A2 } \\
\text { Smi-A21 }\end{array}$ & $\begin{array}{l}\text { SD } \\
\text { SD }\end{array}$ & Kepala Pasar & $178 \mathrm{KM}$ \\
\hline 8 & A2-Oka & $36 \mathrm{yrs}$ & SMK & Non-Job & Oka-A2 & SD & Ulak Pandan & $189 \mathrm{KM}$ \\
\hline 9 & A2-Sas & $39 \mathrm{yrs}$ & SMA & Staff SD & Sas-A2 & SDIT & Penanding & $39 \mathrm{KM}$ \\
\hline 10 & A1-Nnk & $41 \mathrm{yrs}$ & SMP & Fisherman & Nnk-A1 & $\mathrm{SD}$ & Kahyapu & $200 \mathrm{KM}$ \\
\hline 11 & A4-Amr & $34 \mathrm{yrs}$ & Strata 1 & Non-Job & Amr-A4 & SD & Urai & $102 \mathrm{KM}$ \\
\hline 12 & A1-Rzk & $39 \mathrm{yrs}$ & SMP & Housemaid & Rzk-A1 & SD & Pasar Tebat & $36 \mathrm{KM}$ \\
\hline 13 & A1-Rvi & 41 yrs & SMP & Farmer & Rvi-A1 & SD & Penanding & $49 \mathrm{KM}$ \\
\hline 14 & A4-Nhn & $35 \mathrm{yrs}$ & Strata 1 & Farmer & $\begin{array}{c}\text { Nhn-A4 } \\
\text { Nhn-A41 }\end{array}$ & $\begin{array}{l}\text { SD } \\
\text { SD }\end{array}$ & Ujung Karang & $106 \mathrm{KM}$ \\
\hline 15 & A3-Mla & $38 \mathrm{yrs}$ & D III & Seller & Mla-A3 & SD & Karang Anyar & $70 \mathrm{KM}$ \\
\hline 16 & A4-Chr & $43 \mathrm{yrs}$ & Strata 1 & Non-Job & $\begin{array}{c}\text { Chr-A4 } \\
\text { Chr-A41 }\end{array}$ & $\begin{array}{l}\text { SD } \\
\text { SD }\end{array}$ & Rena Semanek & $124 \mathrm{KM}$ \\
\hline
\end{tabular}

Tabel 1. The Participants' Demographic Data

\subsection{Data Analysis}

In analyzing the data of the mothers' struggles, the combined method of Riessman [20] and Miles \& Huberman [24] were applied. Our team contacted participants via telephone with a recording device installed under their consent. Recording was then transcribed verbatim from local language into Indonesian. This applied to each interview in one unit, which was then filtered into codes and finally grouped by categories.

The analysis was conducted in five steps. First, the interviews were transcribed and verbally translated. Second, the transcript was thoroughly read to find the part of the answer that needs to be explored further for the second stage interview if necessary. The third step involved a period of deep reflection in each individual interview. The keywords for every utterance, spoken language, and doubt were marked. Fourth, each keyword from one participant was compared to the keywords used by other participants. Fifth, the same keywords were grouped in a sub-category. Finally, sub-categories were grouped into several main categories, so the accurate data were finally established.

Table 2. Qualitative Interview Guide

\begin{tabular}{cl}
\hline No & \multicolumn{1}{c}{ Interview Questions } \\
\hline 1 & Can you tell us about your family's current situation? \\
2 & What do you think of the learning system that your children are currently \\
& experiencing? \\
3 & Can you tell us about your experiences from the beginning until now providing \\
& support to your children in doing the school work? \\
4 & Can you talk about the challenges you have in assisting children's learning? \\
5 & In your opinion, can you find solutions for any difficulties you encounter? \\
6 & Is there anything else you want to share with us about your experience in \\
& assisting children's learning?
\end{tabular}




\section{Findings}

The results showed that the struggles of mothers in assisting children's learning during Covid-19 was divided into several categories: the struggle of knowladge, the struggle for technology, the struggle for economy the struggle for emotional, and the physical struggle. The sub-findings were ranked based on the from the primary data which showed the frequency of occurance of each category.

\subsection{The Knowladge Struggle}

The highest percentage of experiences shared by the participants was the struggle for knowladge. Mothers wre demanded to understand student assignments, find the pages for the assignment given, learn the materials, and teach them to their children. This was the impact of the rules of the task given by the teacher. Generally, a teacher handed out several questions or instructions. Answers to questions were available in the Student Worksheet (LKS), textbooks from school, or other relevant textbooks. Frequently the teacher combined textbook learning with online media, such as learning from Youtube, where students were instructed to understand video content and explain it. There was also a combination of textbook learning with environmental or natural conditions, for example students were asked to name vertebrate animals around the house. Two mothers described the assignment and and their response to it:

"...Sometimes the assignments given by teachers at school are easy. I understand mathematical calculation or multiplication. But there are also teachers who are unreasonable. At that time my son was asked to look for frogs ....My husband and I were forced to go to the rice field in the afternoon. The first day we could not find any, finally the next day the neighbors helped us to get one. I couldn't do anything about this matter. My child, if he is not able to do his schoolwork, he cries. " (A2-Arm, first interview)

"My son, who is in grade 5 (Smi-A21), has a unfair assignment, but for one subject only. I think the Culture and Arts teacher does not understand the situation and conditions. I was told to make bamboo satay fan. We live by the sea, so there is no bamboo around... I told the children, just make it from coconut leaves. I don't care if the teacher is angry, as long as my child has a satay fan job." (A2-Smi, first interview).

Other participants focused more on the new knowledge they were forced to learn. Mothers were demanded to understand all subjects in school. At the elementary level, there were at least seven subjects: bahasa Indonesia Mathematics, Science, Social Science, Religion, Arts and Culture, and Physical and Health Education. Mathematics was still the most difficult subject while Science was considered as a demanding subject because the assignment given was directly related to environment. According to A3-Mla:

"I am the one who always dislikes mathematics. During this Covid-19 I have to guide children to learn mathematics. Especially if it's about square numbers, I have to open Youtube. So basically recall my old school days. " (A3-Mla, first interview)

In the second interview, A3-Mla added that when he did not understand the lesson, he would contact the teacher via the Whatsapp video call application. Although most of the mothers complained about having to go back to studying to finish their children's school work, it was not a problem for those who once attended high school education. 
For the participants with rather high education level, teaching children may be an easy job, but mothers with low level of education, this became very challenging. A participant shared her experience:

"... have forgotten that lesson (that is, mathematics). That was a long time ago, about 30 years ago. Moreover, I am not smart, I once failed a class, so oftentimes Ican't help my children doing the homework. Rvi-A1. I drove to his grandmother's house, there was his cousin who had studied at IAIN Bengkulu. "(A1-Rvi, second interview)

A1-Rvi emphasized that she had difficulty accompanying her children because it was difficult to focus on the reading resources. Especially for some subjects she said 'have fear in the past'. During Covid-19, children were assisted if she understood the purpose of the assignment given by the teacher. There were three other participants sharing the same experiences as A1-Rvi. In fact, A2-Nta admitted that she did not pay too much attention to her children's school work.

"...I don't understand, especially when it comes to math or bahasa Indonesia.

They make me confused. Looking at numbers make me dizzy. When I am too overwhelmed with the stuff, I just leave it alone." (A2-Nta, second interview)

\subsection{The Technology Struggle}

The women who taking part in this study shared their stories how they were forced by the situation to learn to use smartphones. This did not apply to all participants, however, only those who did not use a smartphone. We found mothers over the age of 38 had more difficulty than others. A4-Chr stated:

"... I have no option; I have to learn to use it. So far I only use monochrome phone... So, I ask the neighbors to help me with smartphone. Once I am used to it, then I monitor my child. But what the funny from this is that my children is a better user than me. But still, I accompany them to make sure they didn't play the snake game. " (A4-Chr, first interview)

A1-Rvi has another way. She trusted his niece who studies at IAIN Bengkulu. During the pandemic, learning activities for all levels of school were transferred to the learning system from home. This was an opportunity to A1-Rvi to take advantage of the situation. She believed his child would study seriously, even without her assistance. So that she could continue the work. When there was an online assignment from the teacher, in the morning her husband would take their kid to the cousin's house. They would pick up the child in the afternoon after returning from work in the fields.

All of the participants came from villages far from the city / district. There were even two participants coming from Enggano Island. Even though it was part of North Bengkulu Regency, he distance from Enggano Island to Bengkulu Utara or Bengkulu City was about $200 \mathrm{~km}$. In this remote village it was difficult to use smartphone devices. Ideally, a teacher did not use internet devices to give assignments or access reading resources, but the fact was there were teachers who deliberately used the internet or parents who were forced to find other sources of knowledge from the internet. In the struggle to find signal, some of the participants narrated their stories, and here were four of which that we share:

"I accompanied the children to the village boundariy. There was a market, in the corner of the market there were locations where other villagers used to look for signals." (A4-Nhn, first interview) 
"His father went up to the balcony, then my child was screaming from below ... Not that there is no signal, in the living room sometimes signals were sometimes lost... what appears most of the time is only the word 'edge', then there is a flickering arrow. If the signaling stem is full, there are four stems. " (A3-Rya, first interview)

"... good signal. But if the lights go out, the internet signal is lost. When there is a heavy rain, the signal is also gone .... It often rains here, because it's a mountainous area. Electricity blackout frequently happens here. " (A1-Rvi, first interview)

"... There is sometimes signal of Telkomsel. My son was taken by his brother, usually under the transmitter tower to find a signal. " (A1-Rzk, second interview)

When they were asked what they did when bad signal wasn't resolved, most parents surrendered because they knew the teacher could understand the limitations. But A4-Wda was looking for another way:

"Last month there was an incident, the father of Wda-A41 actually went to the teacher's house to talk about the situation. Usually the teacher would understand.

" (A4-Wda, second interview)

\subsection{The Economic Struggle}

A lot of research and information in the mass media suggested that farmers, fishermen, and laborers in rural areas were experiencing economic struggle. They survived from day to day. Likewise, the participants of this research were outraged when asked about how their economic conditions were when Covid-19 hit? Some said that they did not fully impact, but there were also those who claimed that they owed several times at the e-credit shop. A2-Hna actually blamed the education policy makers that issued the \#dirumahaja and \#wfh policies, but it was not supported by learning subsidies.

"Yeah ... the schools did as they liked. They asked children to do many things.

However, we still pay for the school tuition. They should help the children to

buy credit, not only give so much schoolwork. Yes ... do not just say \# home, but there is no help. What do you want to eat? Tomorrow what do you want to eat? Yes ... the credit is still in debt until now. 33,000. Last week her sister bought internet quota. "(A2-Hna, first interview)

A2-Hna explained that her husband experienced a reduction in work hours as a handyman because the owner of the house where he worked was unable to pay wages. During Covid-19, A2-Hna, which initially only focused on raising children, has offered several times as a cleaning service in the village office and several residents' homes. Apparently, she said that the temporary work she took actually had a negative impact on his child. We saw an awareness that her child who was still in grade 2 needed a companion.

We did the second interview to A2-Hna, focusing on the question "how is the continuation of the children's learning assistance at home, when you work temporarily outside?" This was considered important to be explored in order to know the solution of economic problems versus children's education.

"I now help washing, ironing, and taking care of neighboring children in the village. Alhamdulillah, you can help a little (family economy). Hna-A2 is studying with her brother. " (A2-Hna, second interview)

At the end of the A2-Hna talk, she explained that Hna-A2 was not a type of child who was easy to control. His brother frequently reported that Hna-A2 was difficult to study with. 
His mother admitted that sometimes she used physical violence and threats to force her children to study.

We have explained before that A4-Chr who only had a monochrome type cellphone before Covid-19, was forced to buy a smartphone

"For me, this old cellphone is enough. It can be used to make a call, send a text,

that's enough. But because it is impossible to continue to ask help to our neighbors, finally, Chr-A41 bought one. The price is quite expensive, we have to postpone the Eid al-Adha sacrifice this year, may Allah SWT replace it with something better. Actually we were hesitant to buy this cellphone. However, internet signals are difficult in our home. " (A4-Chr, second interview)

Mothers usually borrowed a smartphone owned by a neighbor or they had their own cellphone, but they were not understand how to use it is a kind of technology struggle that were also experienced by mothers. There were also cases of paying a number of 'services' because a mother asks for an internet quota every time accompanying her child looking for a task on a neighbor's smartphone.

"Luckily one of my neighbors installed wifi. Since online school is system, I accompanied my children there. It is usually in the morning or evening, depending on my work time at rice field. in We did not visit out neighbor at mid day because we afraid that we disturb their resting time ... Initially I gave 50,000 to my neighbor, but he refused. I felt bad. Finally I decide to bring fruits or snacks, sowe can eat together. "(A1Uta, third interview)

\subsection{The Emotional Struggle}

The term 'impromptu teacher' has been attached to mothers in assisting children's learning in the Covid-19 times. The term came out of one of the the participants in this research. They expressed a term that contained emotions that they were forced to replace the role of the teacher in school. Most of the mothers stated that rhey were not ready for it because they were required to understand all the subjects. Stress, anger, and grumblingoften arouse when accompanying children who did not understand the explanation of the mother or did not follow the rules.

"My emotions are provoked, just angry innate. Being instructed to answer the questions, this child instead run away to his friend's house. I looked for him and told him to go home. When he was at home, he just opened the book for 5 minutes then he was sleepy. How couldn't I not angry? " (A2-Oka, second interview)

Was there physical violence? Some parents admitted that there were pinches, beatings, and other punishments. They believe that physical punishment needed to be given in order to frighten children. But they limit all of this above fairness.

"My parents are like that to me too. It's been hereditary. When we are in the village, scolding children accompanied by pinching is common. Most of our children cried and the next day he repeated it. " (A2-Hna, second interview)

A4-Wda used an agreement mechanism to her children before learning began. A4-Wda provided several punishment options if the child did not do the exercise assignments from school. At the same time she promised to give an award if the child was able to follow the rules of the game from beginning to end. The child could determine where he would go. This pattern could be made effetive perhaps because $\mathrm{A} 4-\mathrm{Wda}$ had the experience of educating children as a teacher. He understood the best way to encourage children to compromise. 
Among the mothers, it turned out there were those who use the Islamic approach in overcoming the emotional affliction. When children were unable to be controlled, mothers prefer to use sedative sentences in Islam such as 'astagfirullahaladzim', 'O Allah', and 'subhanallah'. We asked if the sentence would calm their emotions.

"You don't want to push your children too hard. I am afraid he is traumatized.

All I could do is to be patient ... The words 'astagfirullahaladzim' just come out of my mind as a reflective response. I don't know, but I feel better after reciting it. Most later accompanied also by praying after the prayer. Asking Him to be given more patience in raising children. " (A4-Amr, second interview)

"I am like this, ha ... ha ... ha ... recite" astagfirullah 'but followed by an angry

face. Like there is emphasis. Scared child. ha..ha..ha .. and it worked out. " (A2-

Sas, first interview)

Physical fatigue also affected parents' emotions when accompanying children's learning. Mothers who helped their husbands meet family needs had more stress levels than mothers who only focused on raising children. We have found that there was a common sanse in the community that children's education is in the hands of mothers, so that the husband could enjoy a break in the afternoon or evening. This is inseparable from the explanation of several participants that they get a greater share of work than their husbands. After work, mothers still had to do homework and take care of children. A2-Hna was willing to share unusual stories

"... I have a limit, if I have too much to do and think of, I just want to be angry

... yesterday, there was an incident when my child played all day. I told him do assignments, but he instead went to sleep ... It had reached its peak (my emotion), so I hit him using a broomstick ... "(A2-Hna, second interview)

As has been mentioned above that for A2-Hna hitting children is a common thing in their families. That has been their way of ensuring the child's ethics in the future. Emotions that arouse from mothers which drove to physical reactions was another form of their love for children.

\subsection{The Physical Struggle}

The physical struggle in this context was the physical sacrifice of a mother during the child's learning times in this current situation. We noted that there were three mothers who fell down from motorbikes and had a fever. A1-Rzk suffered a sprained fall from the motorcycle when she took her son to the transmitter tower to get an internet signal. She considered the incident as an unwary in carrying a motorbike on the red dirt road after rain. Nevertheless, A1Rzkwas still grateful that her child did not experience any injuries. She said:

"... the task would actually submitted the next week, I was going to a stall to buy

LPG. Because I went through the tower area, all Rzk-A1 were coming along.

The asphalt road did not reach the tower area, and the pathway was red soiled and wet. There I fell down from my motorcycle.. " (A1-Rzk, second interview)

A1-Rzk went to the village masseur to relieve the pain. The treatment took place three times a week. During the treatment, the task of assisting the learning child continued to be carried out. A1-Rzk considered the accident as part of the risk of meeting the educational needs of the child. When telling this part, A1-Rzk cried:

"My husband only completed elementary school, and I graduated junior high school. I work as a maid at someone's home. I want a better work, but I have no high school's degree. It's enough for us to be like this, my child, should have better condition than us. " (A1-Rzk, second interview) 
Physical struggle was also experienced by A4-Nhn because they had to balance work as farmers while supervising two children in grades 2 and 6 elementary school. This situation became difficult because her husband had just died last year. So that the whole work was done all by herself. Frequently she expereinced back pain and fever.

"... After going back from the rice field that afternoon, I felt so depleted. In the evening I have to watch over my child. Because physically exhausted, I often catch a cold. Usually that is after helping my children with their assignment, I ask them to help me to use the balm to relieve pain. " (A4-Nhn, second interview)

As can be seen from the explanation of A4-Nhn, physical condition did not become an obstacle to continue supervising children to learn during the Covid-19.

\section{Discussion}

The struggle of mothers in assisting children's learning in the Covid-19 outbreak era based on research data includes the struggle for knowledge, technology, economics, emotional, and physical. Their stories reflect the complex dynamics inherent in meeting the educational needs of children. Also as sub-ordinates stressed the importance of their efforts as a companion and supporter of the family economics in the context of their culture, biographical environment, and social order.

The most dominant thing narrated by mothers is the struggle for knowledge. There are efforts to re-learn, but not a few who gave up because they were unable to understand the child's subjects. We see parents who have a good educational background, the task of mentoring is much easier than parents who lack education. Access to new knowledge includes learning to use a smartphone or certain applications suggested by the teacher. Luckily for parents who can afford to buy a smartphone and internet quota, but it is a problem for those who have economic difficulties. We feel compelled to buy it or find other solutions such as using other people's devices. We also find emotional struggles in the form of stress, anger because children are difficult to regulate, curses in the heart, and also patient. Some parents calm-down using Islamic readings: 'Astaghfirullah, Allahu Akbar, SubhanAllah'. Physical fatigue and pain are also part of the struggle of mothers. They claimed to have no objections even though they worked during the day and at night with their children. There is a strong desire to provide the best for children, even though they must ignore health. We clarify all their struggles on a sincere basis to ensure the future success of children.

The findings are connected with previous studies for several things such as during Covid-19 mothers at home replacing the role of the teacher [25], psychological stresses experienced [5],[6],[7], technological limitations [26], and economics [27],[28],[4]. But what was unexpected and not yet conveyed in previous studies, and at the same time became a characteristic finding in this study, is the physical sacrifice of fatigue and pain. Although this cannot be said to be full because it accompanies children's learning. Our informants are tough women who take part in family welfare efforts, completing homework: washing, cooking, sweeping, and caring for children. This finding is supported by the explanation of Malik and Naeem that rural women work far harder than men [29]. Yet for the enlightenment of education, patriarchal societies rarely provide that opportunity. A recent study conducted in the village of Bihar, India, described the exploration of female labor during the Covid-19 period tended to increase [28]. A recent United Nations report that rural women find it more 
difficult to get health services during a pandemic. Social norms and gender stereotypes are still the main reasons [27].

The findings, analysis, and study support have supported our argument that specifically in the context of the true regional education policy in the Covid-19 period which forced children to study at home, bringing mothers to face unpredictable situations and surrender. For some of our participants who have sufficient resources, the unpredictable conditions can be overcome. But mothers who are not ready, they prefer to surrender.

Finally, we encourage policymakers to take steps to intervene. In the context of regionalism, it is very difficult to refer only to the general rules in the Minister of Education and Culture Circular Letter No. 4 of 2020. Dinas Pendidikan (District Education Office) should not be focused on these appeals. Important to take interventions such as proposing cuts in school fees, provision of quotas free, easy access to reading material, or other supporting policies. Even interventions need to be taken up to the school level, such as providing consultation of students and parents, cutting non-urgent costs, simplifying tasks by teachers, and providing online training and ICT.

\section{Conclussion and Limitations}

The findings reported here indicated knowledge, technology, economics, emotional and physical are a form of the mother's struggle in the rural assisting their children's learning during the Covid-19. We highlight the importance of educational policy interventions in times of crisis both by District Education Office or at the school level. This study provides a unique understanding of the experience of rural women in meeting the educational needs of their children. Also the way they interpret the importance of education to change the fate of future families.

Research findings are still considered to have a limited sample of mothers who are able to speak and participate in interviews. Therefore, there may be other findings if mothers in other remote areas have the opportunity to talk. In addition, this study only explores the struggles of mothers in assisting children's learning in the most difficult times of the Covid-19, marked by general policy interventions. The experience will change with the times. It seems interesting to see the learning of parents with children, both the new normal or after a pandemic is over. Finally, we also suggest future studies to highlight best practices in educational policy interventions in times of crisis.

\section{Disclosure statement}

No potential conflict of interest was reported by the authors.

\section{References}

[1] R. E. Glover et al., "A framework for identifying and mitigating the equity harms of COVID-19 policy interventions," J. Clin. Epidemiol., 2020, doi: 10.1016/j.jclinepi.2020.06.004.

[2] A. Yousefpour, H. Jahanshahi, and S. Bekiros, "Optimal policies for control of the novel 
coronavirus disease (COVID-19) outbreak," Chaos, Solitons and Fractals, 2020, doi: 10.1016/j.chaos.2020.109883.

[3] M. Nicola et al., "Health policy and leadership models during the COVID-19 pandemic: A review," International Journal of Surgery. 2020, doi: 10.1016/j.ijsu.2020.07.026.

[4] R. M. Viner et al., "School closure and management practices during coronavirus outbreaks including COVID-19: a rapid systematic review," The Lancet Child and Adolescent Health. 2020, doi: 10.1016/S2352-4642(20)30095-X.

[5] X. Xie et al., "Mental Health Status among Children in Home Confinement during the Coronavirus Disease 2019 Outbreak in Hubei Province, China," JAMA Pediatrics. 2020, doi: 10.1001/jamapediatrics.2020.1619.

[6] M. Spinelli, F. Lionetti, M. Pastore, and M. Fasolo, "Parents' Stress and Children's Psychological Problems in Families Facing the COVID-19 Outbreak in Italy," Front. Psychol., 2020, doi: 10.3389/fpsyg.2020.01713.

[7] D. K. Ahorsu, C. Y. Lin, V. Imani, M. Saffari, M. D. Griffiths, and A. H. Pakpour, "The Fear of COVID-19 Scale: Development and Initial Validation," Int. J. Ment. Health Addict., 2020, doi: 10.1007/s11469-020-00270-8.

[8] S. K. Brooks et al., "The psychological impact of quarantine and how to reduce it: rapid review of the evidence," The Lancet. 2020, doi: 10.1016/S0140-6736(20)30460-8.

[9] T. G. Szabo, S. Richling, D. D. Embry, A. Biglan, and K. G. Wilson, "From Helpless to Hero: Promoting Values-Based Behavior and Positive Family Interaction in the Midst of COVID-19," Behav. Anal. Pract., 2020, doi: 10.1007/s40617-020-00431-0.

[10] G. Wang, Y. Zhang, J. Zhao, J. Zhang, and F. Jiang, "Mitigate the effects of home confinement on children during the COVID-19 outbreak," The Lancet. 2020, doi: 10.1016/S0140-6736(20)30547$\mathrm{X}$.

[11] Deb Amlen, "Running Out of Games? Remember These Old-School Favorites. The New York Times," 2020.

[12] Stephanie Osmanski, "Avoid Cabin Fever with These 125 Ideas to Keep Kids Entertained During the Coronavirus Crisis," 2020.

[13] M. S. Dewi, "RESPON ORANG TUA TERHADAP PEMBELAJARAN DARING PADA MASA PANDEMI COVID-19," THUFULI J. Ilm. Pendidik. Islam Anak Usia Dini, 2019.

[14] N. Cahyati and R. Kusumah, "Peran Orang Tua Dalam Menerapkan Pembelajaran Di Rumah Saat Pandemi Covid 19," J. Golden Age, Univ. Hamzanwadi, 2020.

[15] F. F. Hikam, "Peran Keluarga Dalam Pembelajaran Berbasis E-Learning Pada Masa Wabah Covid19," J. Pendidik. dan Dakwah, 2020.

[16] E. Luthfi and F. Ahsani, "Strategi Orang Tua dalam Mengajar dan Mendidik Anak dalam Pembelajaran At The Home Masa Pandemi Covid-19," J. Al Athfal, 2020.

[17] T. Z. Y. Wardhani and H. Krisnani, "OPTIMALISASI PERAN PENGAWASAN ORANG TUA DALAM PELAKSANAAN SEKOLAH ONLINE DI MASA PANDEMI COVID-19," Pros. Penelit. dan Pengabdi. Kpd. Masy., 2020, doi: 10.24198/jppm.v7i1.28256.

[18] M. M. Jæger and E. H. Blaabæk, "Inequality in learning opportunities during Covid-19: Evidence from library takeout," Res. Soc. Stratif. Mobil., 2020, doi: 10.1016/j.rssm.2020.100524.

[19] N. Kapasia et al., "Impact of lockdown on learning status of undergraduate and postgraduate students during COVID-19 pandemic in West Bengal, India," Child. Youth Serv. Rev., 2020, doi: 10.1016/j.childyouth.2020.105194.

[20] C. K. Riessman, "Narrative Methods for the Human Sciences," Narrat. Inq., 2008, doi: 10.1075/ni.18.2.13ada.

[21] G. Caduri, "On the Epistemology of Narrative Research in Education," J. Philos. Educ., 2013, doi: 10.1111/1467-9752.12011.

[22] J. Elliott, "Using Narrative in Social Research: Qualitative and Quantitative Approaches," Using Narrat. Soc. Res., 2005, doi: 10.4135/9780857020246.

[23] L. Webster and P. Mertova, Using narrative inquiry as a research method: An introduction to using critical event narrative analysis in research on learning and teaching. 2007.

[24] M. Miles and A. Huberman, "Miles and Huberman Chapter 2," in Qualitative Data Analysis, 1994. 
[25] E. Kurniati, D. K. Nur Alfaeni, and F. Andriani, "Analisis Peran Orang Tua dalam Mendampingi Anak di Masa Pandemi Covid-19," J. Obs. J. Pendidik. Anak Usia Dini, 2020, doi: 10.31004/obsesi.v5i1.541.

[26] UCLG, "Briefing \& Learning Note: Digital Technologies and the COVID19 Pandemic," 2020. https://www.uclg.org/sites/default/files/eng_briefing_technology_final_x.pdf.

[27] UN Women, "Policy Brief: The Impact of COVID-19 on Women," $20 \overline{20}$.

[28] D. Kumari, "Livelihood Issues amongst Scheduled Caste Women in Rural Bihar in the Outset of COVID-19 and the Way Ahead," SSRN Electron. J., 2020, doi: 10.2139/ssrn.3646395.

[29] S. Malik and K. Naeem, "Policy Review Impact of COVID-19 Pandemic on Women Health, livelihoods \& domestic violence," pp. 1-11, 2020, [Online]. Available: https://www.jstor.org/stable/resrep24350. 